STUDIA Z PRAWA WYZNANIOWEGO

Tom $24-2021$

DOI: https://doi.org/10.31743/spw.12586

GRZEGORZ MARON*

PIOTR STECZKOWSKI**

\title{
ODWOŁANIA DO CHRZEŚCIJAŃSTWA W KONSTYTUCJACH WSPÓŁCZESNYCH PAŃSTW
}

References to Christianity in constitutions of contemporary states

Streszczenie: W niniejszym artykule poddano analizie ilościowej i jakościowej konstytucyjne odwołania do chrześcijaństwa. W ramach przeprowadzonego studium obowiązujących ustaw zasadniczych poszczególnych państw ustalono skalę odniesień do chrześcijaństwa oraz odniesienia te poddano systematyzacji i typologizacji. Tytułowymi odwołaniami do chrześcijaństwa objęto zarówno bezpośrednie wzmianki o chrześcijańskich zasadach, wartościach czy dziedzictwie, jak i odwołania implikatywne, tj. do Boga pojmowanego zgodnie z monoteistycznym trynitaryzmem oraz do poszczególnych chrześcijańskich denominacji, ich wyznawców i kościołów. Ze względu na historyczno-kulturowy, a nie tylko religijny wymiar chrześcijaństwa, odwołania do niego w konstytucjach co do zasady nie przeczą bezstronności światopoglądowej władz publicznych, nie prowadzą do konfesjonalizacji państwa, ani nie naruszają praw wyznawców innych religii i osób bezwyznaniowych. Egzageracją jest odbieranie odwołań tego typu przez niechrześcijan jako działań ich rzekomo społecznie alienujących i wykluczających. Od ustrojodawcy decydującego się na wyróżnienie chrześcijaństwa w konstytucji należy oczekiwać kierowania się wolą suwerena. Inkorporowanie do ustaw zasadniczych odniesień do chrześcijaństwa nie powinno jednak być narzędziem inżynierii społecznej o celach prozelickich.

Słowa kluczowe: konstytucje; chrześcijaństwo; Kościół; metoda prawno-porównawcza

* Dr hab., prof. UR, Zakład Nauk Historyczno i Teoretyczno Prawnych, Instytut Nauk Prawnych, Uniwersytet Rzeszowski, ul. Grunwaldzka 13, 35-068 Rzeszów, e-mail: gmaron@ur.edu.pl. ORCID 0000-0002-3861-9103.

${ }^{* *}$ Ks. dr hab., prof. UR, Zakład Prawa Rzymskiego, Instytut Nauk Prawnych, Uniwersytet Rzeszowski, ul. Grunwaldzka 13, 35-068 Rzeszów, e-mail: psteczkowski@ur.edu.pl. ORCID 0000-0002-5082-7757. 
Abstract: The present paper offers a quantitative and qualitative analysis of constitutional references to Christianity. An examination of binding basic laws of individual states allowed the authors to determine the scale of references to Christianity and to systematize and typologize these references. As assumed in the study, "references to Christianity" include both direct mentions of Christian principles, values or heritage as well as implicit ones, i.e., references to God understood in accordance with monotheistic Trinitarianism and to individual Christian denominations, their followers and churches. Due to the fact that Christianity not only has a religious, but also a historical and cultural dimension, its references in the constitutions, in principle, do not deny the ideological impartiality of public authorities or lead to confessionalisation of the state. Neither do they violate the rights of followers of other religions and non-believers. It is an exaggeration to perceive constitutional references to Christianity by non-Christians as allegedly socially alienating and excluding. The constitutional legislator deciding to distinguish Christianity in a constitution is expected to be guided by the will of the sovereign. However, incorporating references to Christianity into basic laws should not serve as a tool of social engineering for proselytic purposes.

Key words: constitutions; Christianity; Church; comparative legal method

\section{WPROWADZENIE}

Problematyka konfesyjna w konstytucjach stanowi przedmiot komparatystycznego zainteresowania krajowej i zagranicznej jurysprudencji, najczęściej przedstawicieli dogmatyki prawa konstytucyjnego i wyznaniowego ${ }^{1}$, a także reprezentantów pozaprawnych nauk społecznych ${ }^{2}$. Zwykle dociekania doktryny prawniczej ogniskują się wokół problematyki wolności religii jednostki oraz pozycji prawnej kościołów i innych związków wyznaniowych, czyli odpowiednio zagadnień praw człowieka i kwestii ustrojowych ${ }^{3}$. W mniejszym zakresie, choć nie sporadycznie, porównawczej analizie poddaje się inne zagadnienia, jak choćby invocatio $D e i$ w ustawach zasadniczych ${ }^{4}$. Rzadko natomiast podejmowanym obsza-

Zob. Yakobson 2013, 1-13.

2 Zob. Flere, Lavrič, Djordjević 2017, 466-488.

3 Zob. Safjan 2003, 43-73; Orzeszyna 2007; Naumann 2008.

4 Zob. Bała 2011, 305-333; Iban 2013, 37-55; Krukowski 1996, 202-214; Neo 2017. 
rem badawczym są odwołania w konstytucjach do poszczególnych religii i wyznań ${ }^{5}$.

W niniejszym artykule przedstawiono rezultaty naukowej eksploracji konstytucji państw współczesnych ${ }^{6}$ pod kątem obecności w nich odwołań do chrześcijaństwa ${ }^{7}$. Przeprowadzone komparatystyczne studium ustaw zasadniczych ma charakter kwalitatywno-kwantytatywny. Z jednej strony ustalono skalę odniesień do chrześcijaństwa w konstytucjach, z drugiej strony odniesienia te poddano systematyzacji i typologizacji. Osobno rozważono kwestię prawnej doniosłości zamieszczenia w preambule konstytucji nawiązań do chrześcijaństwa oraz zasadności i warunków inkorporowania odniesień tego typu w najważniejszym akcie normatywnym państwa. W szczególności ustosunkowano się do zarzutów, że wyróżnianie chrześcijaństwa w konstytucji przeczy neutralności religijnej państwa demoliberalnego i różnicuje obywateli na lepszych i gorszych według klucza światopoglądowego.

\section{SKALA ODNIESIEŃ DO CHRZEŚCIJAŃSTWA W KONSTYTUCJACH WSPÓŁCZESNYCH PAŃSTW}

Obowiązujące konstytucje wszystkich państw świata odwołują się do kategorii religii, najczęściej gwarantując wolność religii i zakazując dyskryminacji ze względu na religię ${ }^{8}$, nie wyłączając państw, w których w praktyce osoby wierzące poddawane są prześladowaniom, jak Korea Północna czy Chińska Republika Ludowa. Większość z konstytucji zawiera też odniesienia do Boga, ale już nie do konkretnej religii ${ }^{9}$. Najczęściej wzmiankowaną religią w ustawach zasadniczych jest islam. W konstytucji większości państw formalnie czy demograficznie muzułmańskich znajdują się odwołania do religii Mahometa ${ }^{10}$. Inaczej proporcjonalnie przedstawia się sytuacja eks-

Temperman 2010.

6 Przedmiotem badań są zarówno konstytucje w znaczeniu formalnym, jak i materialnym.

7 W rozważaniach pomijamy zagadnienie odniesień do chrześcijaństwa na poziomie ustawowym. Zob. np. Daniel 1997, 157-207.

8 Por. Henry 2018.

9 Frosini 2012, 42-43.

10 Ferrari 2015, 32-33; Voermans, Stremler, Cliteur 2017, 62. 
plikatywnych odniesień w ustawach zasadniczych do chrześcijaństwa, czyli największej religii wyznawanej przez około 2,4 mld mieszkańców globu, stanowiących blisko 1/3 światowej populacji. Na około 120 państw demograficznie czy kulturowo chrześcijańskich, konstytucje jedynie 13 zawierają expressis verbis odniesienia do chrześcijaństwa ${ }^{11}$, a uwzględniając odniesienia pośrednie oraz odwołania do partykularnych chrześcijańskich denominacji i ich kościołów liczba ta wzrasta do 44 państw. W szacunkach tych należy odnotować także konstytucje 6 państw muzułmańskich, w których wzmiankowane jest literalnie chrześcijaństwo lub chrześcijanie ${ }^{12}$.

\section{BEZPOŚREDNIE ODWOŁANIA DO CHRZEŚCIJAŃSTWA}

W konstytucjach kilku państw, zwłaszcza ich preambułach, pojawiają się odniesienia do chrześcijańskich wartości i zasad. Podobne w brzmieniu odwołania tego typu występują we wstępach do konstytucji trzech państw obszaru Oceanii. Preambuły ustaw zasadniczych Tuvalu, Vanuatu i Wysp Samoa stanowią, że wymienione państwa są „oparte na” m.in. „chrześcijańskich zasadach", co oznacza, że zasady te potraktowano jako element aksjologicznie konstytuujący państwo ${ }^{13}$. Wstęp do konstytucji państwa Papua Nowa Gwinea zawiera deklarację i zobowiązanie suwerena do strzeżenia i przekazywania kolejnym pokoleniom „,chrześcijańskich zasad, które są obecnie nasze" ${ }^{14}$. W preambule konstytucji Wysp Bahama szacunek do „chrześcijańskich wartości” i ich przestrzeganie uznano za jeden z warunków zachowania przez Naród wolności ${ }^{15}$.

11 Są to: Kostaryka, Łotwa, Nikaragua, Norwegia, Panama, Papua Nowa Gwinea, Polska, Tuvalu, Vanuatu, Węgry, Wspólnota Bahamów, Wyspy Samoa, Zambia.

12 Bangladesz, Egipt, Irak, Iran, Liban, Pakistan.

13 Tuvalu (P), Vanuatu (P), Wyspy Samoa (P). Ze względów edytorskich w przypisach poszczególne konstytucje oznaczono, podając nazwę państwa, a obok w nawiasie wskazując właściwy artykuł lub literę „P” symbolizującą preambułę ustawy zasadniczej. Wykaz przeanalizowanych konstytucji wraz z odniesieniami do ich tekstów w językach urzędowych i polskich tłumaczeń zamieszczono w Załączniku. W artykule uwzględniono stan prawny na dzień 1 stycznia $2021 \mathrm{r}$.

14 Papua Nowa Gwinea (P).

15 Wspólnota Bahamów (P). 
W konstytucji Nikaragui postanowiono, że państwo ma „inspirować się" wartościami chrześcijańskimi (obok socjalistycznych ideałów, solidarności, demokracji i humanizmu), działając w celu osiągnięcia dobra powszechnego oraz promując rozwój każdego z Nikaraguańczyków. Chrześcijańskie wartości wskazano także jako jedne z zasad Narodu nikaraguańskiego. Zwraca uwagę, że ustrojodawca zdefiniował te wartości, zaliczając do nich „,braterską miłość, pojednanie pomiędzy członkami nikaraguańskiej rodziny, szacunek dla jednostkowej różnorodności bez jakiejkolwiek dyskryminacji, szacunek dla równych praw osób niepełnosprawnych oraz preferencję dla ubogich"16.

Wśród państw europejskich jedyną konstytucją, której preambuła odwołuje się expressis verbis do chrześcijańskich wartości, jest ustawa zasadnicza Łotwy. Wartości te - obok kilku innych - zaliczono do czynników, które ukształtowały „tożsamość Łotwy w europejskiej przestrzeni kulturowej"17.

Preambuły czterech kolejnych państw zawierają eksplikatywne odniesienia do chrześcijaństwa. Niewątpliwie wyróżnia się pod tym względem wstęp do konstytucji Zambii, w którym ogłoszono „Republikę Chrześcijańskim Narodem" "18. Na kulturo- i narodowotwórczy wymiar chrześcijaństwa wskazują preambuły do konstytucji Polski i Norwegii. W tej pierwszej jest mowa o „kulturze zakorzenionej w chrześcijańskim dziedzictwie Narodu"19. Z kolei w tej drugiej podniesiono, że chrześcijańskie i humanistyczne dziedzictwo „pozostanie naszymi wartościami”20. Podobnego charakteru są dwa odniesienia do chrześcijaństwa w preambule konstytucji Węgier. We wstępie do ustawy zasadniczej wyrażono dumę z tego, że „nasz król, Święty Stefan, tysiąc lat temu osadził państwo węgierskie na solidnych fundamentach i uczynił naszą ojczyznę częścią chrześcijańskiej Europy”. Ponadto uznano „rolę chrześcijaństwa w przetrwaniu narodu”21.

Zróżnicowane tematycznie literalne odniesienia do chrześcijaństwa występują także w części artykułowanej ustaw zasadniczych.

\footnotetext{
16 Nikaragua (art. 4-5).

17 Lotwa (P).

18 Zambia (P).

19 Polska (P).

20 Norwegia (P).

21 Węgry (P).
} 
W konstytucji Samoa - podobnie jak we wstępie do konstytucji Zambii państwo to określono „chrześcijańskim narodem opartym na Bogu Ojcu, Synu i Duchu Świętym"22.

Ustawa zasadnicza Kostaryki stanowi, że prawa i gwarancje socjalne wymienione w rozdziale $\mathrm{V}$ aktu nie wyczerpują tej kategorii, obejmując również inne prawa ,wywodzone z chrześcijańskiej zasady sprawiedliwości społecznej i wskazane w ustawodawstwie"23.

Normatywny, a zarazem prima facie reglamentacyjny charakter jest udziałem art. 35 konstytucji Panamy, który poszanowanie „chrześcijańskiej moralności" czyni jednym z warunków wyznawania i praktykowania innych religii i form kultu ${ }^{24}$. Podobny charakter ma art. 14 ust. 3 lit. a konstytucji Grecji, legitymizujący możliwość konfiskaty prasy w razie ,znieważenia religii chrześcijańskiej lub każdej innej znanej religii’’25.

W konstytucjach kilku państw formalnie i/lub demograficznie islamskich wymieniono chrześcijaństwo wśród prawnie uznawanych religii, a chrześcijan jako wyznawców tej religii ${ }^{26}$. Podobne brzmienie posiada art. 362 ustawy zasadniczej buddyjskiej Mjanmy (Birmy) ${ }^{27}$. Poza samo wzmiankowanie chrześcijaństwa wykracza konstytucja Egiptu. Stanowi ona, że status osobisty chrześcijan, ich sprawy religijne oraz wybór duchowych przywódców podlega prawu wewnętrznemu egipskich chrześcijan. Konstytucja ta zawiera ponadto delegację do wydania przepisów w przedmiocie wznoszenia i renowacji kościołów, traktując ustawodawstwo w tej kwestii za jedną z gwarancji poszanowania wolności religijnej chrześcijan ${ }^{28}$.

Ustawy zasadnicze trzech państw zawierają przepisy dotyczące przedstawicielstwa chrześcijan w różnych organach władzy publicznej. Konstytucja Egiptu gwarantuje reprezentację chrześcijan w pierwszej - po wejściu konstytucji w życie - Izbie Reprezentantów oraz w organach lokalnych ${ }^{29}$, a z kolei konstytucja Libanu wprowadza parytet pomiędzy chrześcijanami

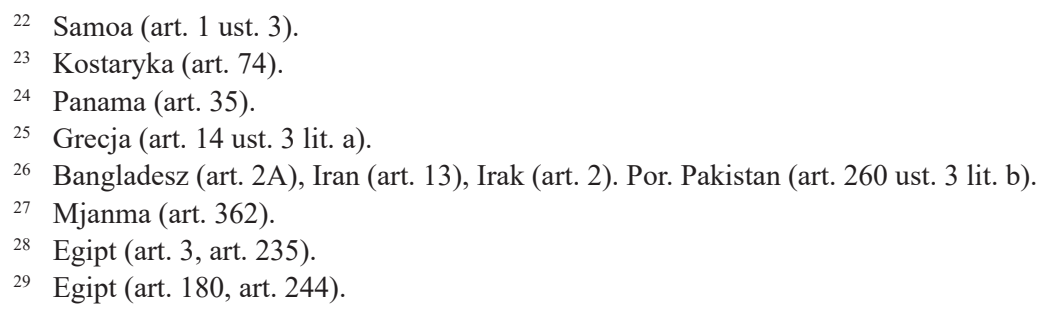


i muzułmanami w Izbie Deputowanych ${ }^{30}$. Konstytucja Ghany wśród członków Narodowej Komisji ds. Mediów wymienia przedstawiciela chrześcijan (Narodowy Katolicki Sekretariat, Rada Chrześcijańska, Rada Zielonoświątkowców Ghany) ${ }^{31}$.

\section{POŚREDNIE ODWOŁANIA DO CHRZEŚCIJAŃSTWA}

Implikatywne odwołania do chrześcijaństwa można podzielić na co najmniej dwie kategorie. Do pierwszej zaliczają się przypadki przywoływania Boga w sposób odpowiadający Jego wyobrażeniu w chrześcijańskiej doktrynie. Na drugą kategorię składają się odniesienia do poszczególnych chrześcijańskich denominacji oraz ich wyznawców i kościołów.

\section{A) ODWOŁANIA DO CHRZEŚCIJAŃSKIEGO BOGA}

Zgodnie z chrześcijańskim dogmatem monoteistycznego trynitaryzmu określono Boga w preambułach konstytucji Grecji (,Święta, Niepodzielna i Współistotna Trójca”) ${ }^{32}$, Irlandii („Najświętsza Trójca”) ${ }^{33}$ oraz w jednym z przepisów konstytucji Samoa („Bóg Ojciec, Syn, Duch Święty”) ${ }^{34}$. Fraza „w imię Trójcy Świętej, Jedynej i Niepodzielnej” występuje w konstytucyjnej rocie przysięgi Prezydenta i deputowanych Grecji ${ }^{35}$. Duch Święty wzmiankowany jest w akcie konstytucyjnym San Marino ${ }^{36}$. W konstytucjach Irlandii i Grecji pojawia się też bezpośrednie odniesienie do Jezusa Chrystusa. W preambule tej pierwszej występuje zwrot „Boski Pan,

30 Liban (art. 24, zob. też art. 95).

31 Ghana (art. 166 ust. 1). Ustawa zasadnicza Haiti, jakkolwiek wprost nie mówi o chrześcijaństwie czy chrześcijanach, to jednak stanowi, że w skład Komisji Wyborczej wchodzi m.in. przedstawiciel Konferencji Episkopatu Haiti oraz wyznań protestanckich Haiti (art. 289).

32 Grecja (P).

33 Irlandia (P). Zob. Kavanagh 2012, 71-101.

34 Samoa (art. 1 ust. 3).

35 Grecja (art. 33 ust. 2, art. 59 ust. 1).

36 San Marino (art. 13, art. 14). 
Jezus Chrystus" 37 . Z kolei konstytucja Grecji stanowi, że Prawosławny Kościół Grecji „uznaje naszego Pana Jezusa Chrystusa za swoją głowę"38. Charakter poboczny ma nadmienienie Jezusa Chrystusa wchodzące w skład daty przyjęcia szwedzkiego Aktu o sukcesji (,w roku Naszego Pana i Zbawiciela Jezusa Chrystusa") ${ }^{39}$ oraz ustawy zasadniczej Watykanu („w Uroczystość Chrystusa Króla Wszechświata”) ${ }^{40}$.

Jeszcze innego charakteru jest wzmiankowanie Jezusa Chrystusa w preambule konstytucji Egiptu. Wskazuje się w niej, że ziemia egipska gościła Dziewicę Maryję i Jej Dziecko, a tysiące męczenników poświęciło życie w obronie Kościoła Jezusa. Zaskakiwać może, iż to w konstytucji państwa muzułmańskiego znalazło się nawiązanie do Jezusa i Maryi ${ }^{41}$.

Wśród konstytucji, w których przywołano chrześcijańskiego Boga, wyróżnia się konstytucja irlandzka. Boga ujęto w niej poniekąd jako suwerena, skoro preambuła stanowi, że od Trójcy Przenajświętszej pochodzi wszelka władza i do Niej - jako ostatecznego celu - muszą być odnoszone wszelkie działania ludzi i państwa. Ponadto we wstępie mowa o ,pokornym uznaniu wszelkich naszych obowiązków wobec naszego Boskiego Pana, Jezusa Chrystusa, Który wspomagał naszych ojców przez wieki próby" ${ }^{42}$.

Specyficznie chrześcijańskiego pojmowania Boga nie suponują natomiast takie Jego określenia, jak „Wszechmogący”, „Stwórca”, „Pan”, obecne także w konstytucjach państw muzułmańskich ${ }^{43}$.

B) ODNIESIENIA DO POSZCZEGÓLNYCH WYZNAŃ CHRZEŚCIJAŃSKICH ORAZ ICH WYZNAWCÓW I KOŚCIOŁÓW

Wymienienie w konstytucji konkretnych chrześcijańskich denominacji i odpowiadających im kościołów jest czymś naturalnym w przypadku

37 Irlandia $(\mathrm{P})$.

38 Grecja (art. 3).

39 Szwecja (Akt o sukcesji).

40 Watykan (data wydania aktu).

41 Egipt (P). O Maryi („Naszej Pani z Meritxeel”) mowa także w przepisach przejściowych konstytucji Andory.

42 Irlandia (P). Por. z „Wszelka władza państwowa, ustawodawcza, wykonawcza i sądownicza, pochodzi, z woli Bożej, od Narodu [...]”. Irlandia (art. 6 ust. 1).

43 Maroń 2019, 12-13. 
państw wyznaniowych, choć samo pojęcie państwa wyznaniowego pozostaje ocenne i nieostre ${ }^{44}$. Wydaje się, że status państwa wyznaniowego coraz częściej ma charakter gradacyjny. Posiadanie przez konkretny kościół przymiotu kościoła państwowego jest tylko ,jednym z" i niekoniecznym wyznacznikiem państwa wyznaniowego. Dlatego też nawet utrata takiej pozycji przez konkretny kościół w państwie nie musi oznaczać, że państwo to przestaje być państwem wyznaniowym, jak w przypadku Norwegii i Szwecji. Ustawy zasadnicze państw tego typu określają nie tylko oficjalną religię, ale niekiedy także kwestie związane ze strukturą i uprawnieniami (przywilejami) państwowego czy narodowego kościoła oraz jego relacjami do władz publicznych.

Rozbudowane regulacje konfesyjne zawiera konstytucja Grecji. Wyznanie prawosławne, a dosłownie ,religia Wschodnioprawosławnego Kościoła Chrystusowego”, zostało określone nie tyle jako „państwowe”, co „dominujące”. Ustawa zasadnicza charakteryzuje Prawosławny Kościół Grecji i wskazuje jego związki z Wielkim Kościołem Konstantynopola. Ustrojodawca odnosi się też do kwestii tłumaczenia Pisma Świętego ${ }^{45}$. Za prawosławne państwo wyznaniowe uznawana bywa również Republika Cypru ${ }^{46}$. Konstytucja uznaje wewnętrzne przepisy Greckiego Kościoła Prawosławnego jako właściwe do oceny narzeczeństwa, małżeństwa, rozwodów, unieważnienia małżeństwa, prawnej separacji, przywrócenia praw małżeńskich lub spraw rodzinnych członków tego Kościoła. Przyznaje mu także pełną autonomię regulowania i zarządzania swoimi sprawami wewnętrznymi i majątkiem. Ponadto przynależność do Greckiego Kościoła Prawosławnego stanowi jedno z kryteriów definiowania społeczności greckiej w Republice Cypru ${ }^{47}$.

Katolickimi państwami wyznaniowymi są, nie licząc Watykanu, Lichtenstein, Malta i Monako. Konstytucja pierwszego z nich uznaje, że „kościół rzymskokatolicki jest kościołem państwowym i jako taki korzysta z pełnej ochrony państwa"48. Konstytucja Malty stanowi, że „Religią

\footnotetext{
44 Zob. Szymanek 2011; Borecki 2017, 223-248.

45 Grecja (art. 3).

46 Gołda-Sobczak 2008, 67-68.

47 Cypr (art. 111, art. 110 ust. 1, art. 2 ust. 1).

48 Lichtenstein (art. 37 ust. 2).
} 
Malty jest religia Rzymskokatolickiego Kościoła Apostolskiego"49. Podobnie w konstytucji Monako wskazano, że „religia katolicka, apostolska i rzymska jest religią państwa" ${ }^{50}$.

Protestanckimi państwami wyznaniowymi, choć nie w jednakowym stopniu, są państwa skandynawskie. W ich konstytucjach pojawiają się nawiązania do kościoła czy wyznania ewangelicko-luterańskiego, zwanego również ewangelicko-augsburskim. Ustawy zasadnicze Danii i Islandii określają ten kościół wprost jako państwowy i wspierany przez państwo ${ }^{51}$. Konstytucja norweska tytułuje ów kościół jako „Norweski Kościół Narodowy" i również stanowi o jego wspieraniu ze strony państwa ${ }^{52}$. Konstytucje trzech wymienionych monarchii wymagają, aby król przynależał do Kościoła Ewangelicko-Luterańskiego ${ }^{53}$. Akt o sukcesji wchodzący w skład konstytucji Szwecji nie tylko uzależnia możliwość sprawowania władzy monarszej od bycia „czystego wyznania ewangelicko-augsburskiego”, ale także nakazuje, aby „książęta i księżniczki Domu Królewskiego” były „wychowywane w tym samym wyznaniu"54. Konstytucja Finlandii odsyła z kolei do ustawy dotyczącej organizacji i administracji Kościoła Ewangelicko-Luterańskiego, który - obok Kościoła Grecko-Prawosławnego - posiada status Kościoła Narodowego ${ }^{55}$. Kościół anglikański jest wymieniany w aktach konstytucyjnych Wielkiej Brytanii ${ }^{56}$.

Niektóre konstytucje, jakkolwiek nie statuują państwa wyznaniowego, to jednak wyróżniają konkretne chrześcijańskie wyznanie czy reprezentujący je kościół. Dystynkcja ta podyktowana jest względami historycznymi i demograficznymi. Zwykle ustrojodawca wymienia wyznanie czy kościół gromadzący największą liczbę wiernych w danym państwie, powiązany z dziejami tego państwa, jego tradycją i kulturą.

\footnotetext{
49 Malta (art. 2 ust. 1).

50 Monako (art. 9).

51 Dania (art. 4), Islandia (art. 62).

52 Norwegia (art. 16).

53 Dania (art. 6), Norwegia (art. 4), Szwecja (Akt o sukcesji).

54 Szwecja (art. 4 Aktu o sukcesji).

55 Finlandia (art. 76). Zob. Czuryk 2015, 76.

56 Human Rights Act, 1998 (art. 10 ust. 6, art. 21 ust. 1 lit. h(e)); Act of Settlement, 1700 (art. 3). Art. 2 ostatniego z wymienionych aktów normatywnych wymienia także „kościół rzymski” i ,religię papistyczną".
} 
Konstytucja Bułgarii stanowi, że ,tradycyjną religią w Republice Bułgarii jest wyznanie prawosławne" ${ }^{57}$. Z kolei konstytucja Gruzji podkreśla „szczególną rolę Gruzińskiego Kościoła Prawosławnego i Apostolskiego w historii Gruzji" 58 .

W konstytucjach czterech państw latynoskich wyróżniono katolicyzm. Konstytucja Panamy uznaje, że ,religia katolicka jest praktykowana przez większość Panamczyków"59. W ustawie zasadniczej Paragwaju wskazano na „dominującą rolę Kościoła katolickiego w historycznej i kulturowej formacji Narodu" ${ }^{60}$. W konstytucji Peru Kościół Katolicki przedstawiono jako „ważny element w historycznej, kulturowej i moralnej formacji Peru” oraz zapewniono o współpracy państwa $\mathrm{z}$ nim $^{61}$. Z kolei zgodnie $\mathrm{z}$ wolą ustrojodawcy argentyńskiego „Rząd Federalny wspiera religię rzymsko-katolicką" ${ }^{92}$. O zasługach Kościoła Katolickiego dla społeczeństwa wspomina także preambuła ustawy zasadniczej Timoru Wschodniego: „Kościół katolicki w Timorze Wschodnim zawsze był w stanie z godnością przyjmować cierpienie całego Ludu, stając po jego stronie w obronie najbardziej podstawowych praw" 63 .

Niektóre konstytucje zawierają przepisy dotyczące dwustronnych relacji pomiędzy konkretnym kościołem chrześcijańskim a państwem (władzami państwowymi). W konstytucjach Andory, Gwatemali i Salwadoru uznano osobowość prawną Kościoła Katolickiego ${ }^{64}$. Konstytucja Paragwaju stanowi, że relacje pomiędzy państwem a Kościołem Katolickim opierają się na „niezależności, współpracy i autonomii” ${ }^{65}$. Podobne postanowienie zawiera ustawa zasadnicza Włoch: „Państwo i Kościół katolicki są, każde we własnym zakresie, niezależne i suwerenne" ${ }^{\text {"66 }}$ Konstytucja Gruzji stanowi natomiast: „Stosunki między państwem a Gruzińskim Kościołem

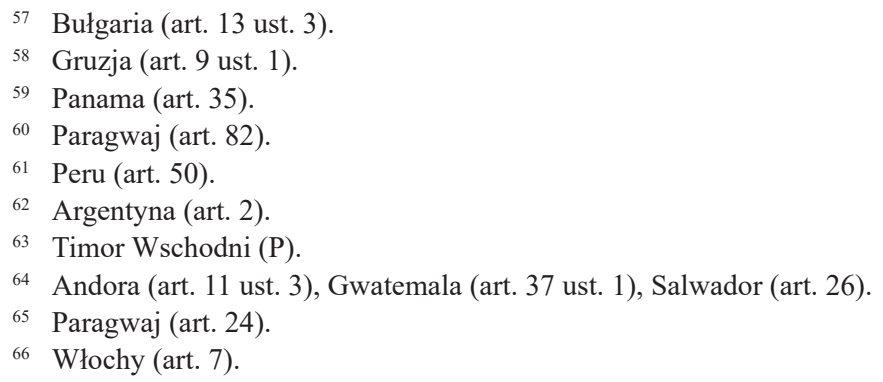


Prawosławnym i Apostolskim określa porozumienie konstytucyjne" ${ }^{67}$. O współpracy państwa z Kościołem Katolickim nadmienia konstytucja Hiszpanii $^{68}$, a o ,szczególnej współpracy zgodnie z tradycją” konstytucja Andory ${ }^{69}$. W polskiej ustawie zasadniczej postanowiono z kolei: „Stosunki między Rzecząpospolitą Polską a Kościołem katolickim określają umowa międzynarodowa zawarta ze Stolicą Apostolską i ustawy"70.

Konstytucje kilku państw wymieniają z nazwy Kościół Katolicki w kontekście gwarantowanych mu uprawnień, takich jak: nauczanie religii w publicznych szkołach ${ }^{71}$, prawo własności nieruchomości wykorzystywanych do własnych celów i stanowiących patrymonium tego Kościoła w przeszłości ${ }^{72}$, prawo własności świątyń wzniesionych w całości czy częściowo ze środków Skarbu Państwa ${ }^{73}$, „swoboda i jawność działalności” oraz uznawanie skutków cywilnych małżeństwa kanonicznego ${ }^{74}$. Trzy kościoły chrześcijańskie, tj. Macedoński Kościół Prawosławny, Kościół Katolicki i Ewangelicki Kościół Metodystyczny wymienia Konstytucja Macedonii Północnej ${ }^{75}$.

Jeszcze innego charakteru są implikatywne odniesienia do chrześcijaństwa obecne w konstytucjach Dominikany i Słowacji. W tej pierwszej określono wizerunek godła Dominikany, którego elementem jest grafika Biblii otwartej na fragmencie rozdziału 8 Ewangelii św. Jana w brzmieniu: ,i poznacie prawdę a prawda was wyzwoli" ${ }^{\text {"76 }}$. Z kolei w preambule słowackiej konstytucji nawiązano do „duchowego dziedzictwa Cyryla i Metodego"77.

67 Gruzja (art. 9 ust. 2).

68 Hiszpania (art. 16 ust. 3).

69 Andora (art. 11 ust. 3).

70 Polska (art. 25 ust. 4).

71 Malta (art. 2 ust. 3, art. 45 ust. 9), Panama (art. 107). Zob. też art. 93 Aktu konstytucyjnego Kanady z 1867 r.

72 Gwatemala (art. 37 ust. 2).

73 Urugwaj (art. 5).

74 Andora (art. 11 ust. 3, art. 13 ust. 1).

75 Macedonia Północna (art. 19 ust. 3 i 4).

76 Dominikana (art. 32).

77 Słowacja (P). 


\section{OCENA KONSTYTUCYJNYCH ODWOŁAŃ DO CHRZEŚCIJAŃSTWA}

Mając na uwadze postępujące procesy sekularyzacyjne można byłoby się spodziewać, że w nowo uchwalanych konstytucjach nie będą się pojawiać wyraźne odniesienia do chrześcijaństwa, a nawet, że w drodze nowelizacji dotychczasowe odwołania do chrześcijaństwa obecne w tekstach ustaw zasadniczych będą usuwane lub redukowane. Studium konstytucji państw współczesnych tej prognozy nie potwierdza, a wręcz dostarcza przykładów przeciwnych. Przyjęta w 2011 r. konstytucja Węgier nie tylko rozpoczyna się inwokacją („Boże, błogosław Węgrów!”), ale także w swej preambule uznaje Węgry za „część chrześcijańskiej Europy” oraz uznaje „rolę chrześcijaństwa w przetrwaniu narodu”78. Rok później dokonano zmian w konstytucji Norwegii polegających m.in. na zmianie brzmienia art. 2. Do tego czasu posiadał on następującą treść: „Religia ewangelicko-luterańska pozostaje oficjalną religią państwa. Mieszkańcy ją wyznający są zobowiązani do wychowywania w niej swoich dzieci”. Po nowelizacji przepis ten uzyskał brzmienie: „Naszymi wartościami pozostaną nasze chrześcijańskie i humanistyczne dziedzictwo [..."'79. Z jednej strony zmiana ta osłabiła status Norwegii jako państwa wyznaniowego ${ }^{80}$, ale reformie ustrojowej w tym przedmiocie towarzyszyło wyraźne wyeksponowanie w konstytucji kulturowej doniosłości chrześcijaństwa.

W 2014 r. dodano preambułę do konstytucji Łotwy. Wartości chrześcijańskie zaliczono w niej do elementów kształtujących tożsamość państwa ${ }^{81}$. Z kolei w 2017 r. do art. 1 konstytucji Samoa dodano ust. 3 stanowiący, iż „Samoa jest chrześcijańskim narodem opartym na Bogu Ojcu, Synu i Duchu Świętym”. Eksplikatywne odniesienie do chrześcijaństwa nastąpiło w sytuacji, gdy preambuła tej ustawy zasadniczej wskazywała, że

78 Węgry $(\mathrm{P})$.

79 Norwegia (art. 2).

80 Uprawnione wydaje się dalsze klasyfikowanie Norwegii jako państwa wyznaniowego. Co prawda konstytucja nie stanowi już, że wyznanie ewangelicko-luterańskie jest oficjalną religią państwa, ale wciąż określa Kościół Ewangelicko-Luterański mianem Norweskiego Kościoła Narodowego wspieranego przez państwo oraz wymaga przynależności do niego monarchy. Zob. Madeley 2017, 29-48.

81 Łotwa (P). 
Samoa jest „oparte na chrześcijańskich zasadach”, a władza w państwie ma być sprawowana w „granicach Bożych przykazań" ${ }^{82}$.

Jedynym państwem, w którego konstytucji w ostatnich dekadach usunięto odwołanie do chrześcijaństwa, jest Fidżi. Preambuła ustawy zasadniczej z 1997 r. wśród kluczowych wydarzeń historycznych dla Narodu Fidżi wymieniała ,przejście rdzennych mieszkańców tych wysp z pogaństwa na chrześcijaństwo mocą imienia Jezusa Chrystusa". Obecnie obowiązująca konstytucja z 2013 r. nie zawiera analogicznej treści. W jej preambule zrezygnowano też z invocatio Dei.

Kwestia zamieszczania w ustawach zasadniczych odniesień do chrześcijaństwa, swoistej ,jurydyfikacji” chrześcijaństwa ${ }^{83}$, od początków konstytucjonalizmu budziła kontrowersje prawne, polityczne i społeczne. Pomimo niewątpliwej doniosłości chrześcijaństwa w powstaniu Stanów Zjednoczonych Ameryki odwołania do tej religii nie inkorporowano do konstytucji z 1787 r., podobnie zresztą pominięto w niej w ogóle nawiązanie do Boga. Niepowodzeniem zakończyła się inicjatywa podjęta w 1864 r. przez przedstawicieli 11 chrześcijańskich denominacji skupionych w National Reform Association, aby zmienić preambułę amerykańskiej konstytucji i dodać do niej następujące sformułowania: „uznając istnienie i przymioty Wszechmogącego Boga, Boskiej Władzy Pisma Świętego, prawa Bożego jako najwyższej normy, i Jezusa, Mesjasza, Zbawcy i Pana wszystkich"84. Szeroką debatę, także wśród prawników, wywołało pominięcie w preambule niedoszłej Konstytucji dla Europy nawiązania do wartości chrześcijańskich czy chrześcijańskiego dziedzictwa i poprzestaniu na sformułowaniu o „kulturowym, religijnym i humanistycznym dziedzictwie Europy”85. W Irlandii od kilkunastu lat formułowane są postulaty usunięcia z ustawy zasadniczej odniesień do chrześcijańskiego pojmowania Boga ${ }^{86}$.

Nawet w tych państwach, w których w ostatniej dekadzie zamieszczono odwołania do chrześcijaństwa w konstytucji, nie nastąpiło to w atmosferze

82 Samoa (art. 1 ust. 3, P).

83 Por. Årsheim, Slotte 2017, 1-89.

84 Kurian, Lamport 2016, 497; Borden 1979, 156-167.

85 Zob. Kozłowski, Gomułka, Latuszewski 2006, 126-137; Suchocka 2008, 733-743; Duda 2006, 71-81; Barbulescu, Andreescu 2009, 207-230; Cvijic, Zucca 2004, 739-748; Menéndez 2005, 179-205.

86 Dineen 2017. 
politycznego i społecznego konsensusu. Przeciwko wpisaniu do preambuły łotewskiej konstytucji „wartości chrześcijańskich” opowiadały się tamtejsze wspólnoty pogańskie, podnosząc, że krzewienie przemocą chrześcijaństwa w Inflantach łączyło się z niszczeniem pierwotnej wiary Łotyszy ${ }^{87}$. Poprawkę do konstytucji Samoa z 2017 r. przegłosowano stosunkiem głosów zaledwie 47 do 43. Odwołanie się do „chrześcijańskiego i humanistycznego dziedzictwa" w norweskiej konstytucji niektórzy komentatorzy, jak T. Lindholm, uznali za „bezwstydnie wykluczające” niechrześcijan ${ }^{88}$.

Oceniając odwołania do poszczególnych religii w konstytucjach, zwłaszcza w ich preambułach, należy wystrzegać się stanowisk skrajnych. Niektórzy autorzy zbyt pochopnie w odniesieniach tego typu doszukują się źródeł konfesjonalizacji państwa stanowiącej zagrożenie dla poszanowania praw obywateli. Przykładem jest krytyka E. Łętowskiej wobec propozycji „odwołania się w preambule Konstytucji RP do ponadtysiącletniego chrześcijańskiego dziedzictwa Polski i Europy jako ważnego źródła naszej tradycji, kultury i narodowej tożsamości”, co było przedmiotem jednego z pytań niedoszłego referendum konsultacyjnego zainicjowanego przez Prezydenta RP, Andrzeja Dudę ${ }^{89}$. E. Łętowska postrzega wprowadzenie do konstytucji cytowanego sformułowania jako „krok w kierunku państwa wyznaniowego”, „otwarcie wrót do nasycania całego systemu prawnego aksjologią kształtowaną nie tylko przez historię myśli chrześcijańskiej, ale i aktualne nauczanie Kościoła katolickiego (bo z innymi kościołami chrześcijańskimi nie mam kłopotu) w kwestiach światopoglądu, kultury i obyczaju”, ,pretekst dla ekspansji konserwatyzmu obyczajowego”, „formalną podstawę ekspansji polityki [...] jednego z kościołów

87 T. Otocki, Z preambuła bezpieczniej?, http://www.new.org.pl/1925-z-preambula-bezpieczniej [dostęp: 29.04.2021].

88 Za: Trigg 2013, 64.

89 Zob. Propozycje pytań w referendum konsultacyjnym, https://webcache.googleusercontent.com/search?q=cache:XpM7hu_wkfsJ:https://www.prezydent.pl/kancelaria/referendumkonsultacyjne/aktualnosci/art,62,propozycje-pytan-w-referendum-konsultacyjnym.htm $1+\& \mathrm{~cd}=1 \& \mathrm{hl}=\mathrm{pl} \& \mathrm{ct}=\mathrm{clnk} \& \mathrm{gl}=\mathrm{pl} \& \mathrm{client}=$ firefox-b-d [dostęp: 01.09.2021]. W ostatecznej wersji pytanie to brzmiało: „Czy jest Pani/Pan za podkreśleniem w Konstytucji RP znaczenia chrześcijańskich źródeł Państwowości Polskiej oraz kultury i tożsamości Narodu Polskiego?", https:/www.prezydent.pl/gfx/prezydent/userfiles3/files/2018_referendum/projekt_postanowienia.pdf [dostęp: 01.09.2021]. 
na tereny prawa" ${ }^{\circ 90}$. Z kolei dla Norweskiego Towarzystwa Humanistycznego art. 2 norweskiej konstytucji przywołujący „,chrześcijańskie i humanistyczne dziedzictwo", obok art. 4 i 16, „ślą sygnał wykluczenia, mogą prowadzić do dyskryminacji albo podważać długą tradycję równego traktowania"91.

Odwrotnym stanowiskiem jest traktowanie odniesień do chrześcijaństwa w konstytucjach wyłącznie w kategoriach historycznych. Przykładowo L. Orgad określa „chrześcijańskie klauzule” w konstytucjach państw europejskich mianem ,archaicznych”. Klauzule te jego zdaniem „mówią więcej o przeszłości i dziedzictwie państwa niż o współczesnym społeczeństwie”, niekoniecznie nawet będąc odwołaniem do „chrześcijaństwa jako religii" ${ }^{92}$.

Rola chrześcijaństwa $\mathrm{w}$ dziejach poszczególnych państw i narodów stanowi obiektywny fakt. Jego uznanie w konstytucji jest wyrazem dziejowej i socjologicznej prawdy, a nie zabiegiem prozelickim czy narzędziem inżynierii społecznej. Doniosłości odniesień do chrześcijaństwa w konstytucjach nie należy przy tym ani przeceniać, ani deprecjonować. Nie sposób zgodzić się z E. Łętowską, że odwołanie się w ustawie zasadniczej do „ponadtysiącletniego chrześcijańskiego dziedzictwa Polski i Europy jako ważnego źródła naszej tradycji, kultury i narodowej tożsamości” doprowadziłoby czy nawet tylko sprzyjało prawnej pozytywizacji moralności katolickiej. Wyrażone przez nią obawy znamionuje dalece posunięta egzageracja. Gdyby prognozy Autorki miały być zasadne, to już obecność w preambule wzmianki o „chrześcijańskim dziedzictwie Narodu” powinna być wykorzystywana do legitymizowania ,prokatolickiego” tworzenia, interpretowania i stosowania prawa. Tymczasem kategoria „chrześcijańskiego dziedzictwa Narodu" bardzo rzadko jest przywoływana w procesie prawotwórczym, a sporadycznie przez polskie sądy. Nawet przyjmując, że uzasadnienie orzeczenia nie jest w pełni miarodajne dla rzeczywistego przebiegu sądowej deliberacji, to i tak niebezpodstawnie można uznać, iż

90 Łętowska 2018.

91 Humanists call on Norway to make constitution more inclusive, https://humanists. international/2019/10/humanists-call-on-norway-to-make-constitution-more-inclusive/ [dostęp: 01.09.2021].

92 Orgad 2017, 76. 
omawiany tu fragment preambuły polskiej konstytucji zasadniczo nie jest brany pod uwagę $\mathrm{w}$ procesie orzeczniczym.

Określenie „chrześcijańskie dziedzictwo Narodu” występuje w zaledwie kilku orzeczeniach zgromadzonych w bazie LEX $^{93}$. Jedynym wskazującym na uwzględnienie przez sąd kategorii chrześcijańskiego dziedzictwa Narodu we własnej argumentacji jest postanowienie Sądu Najwyższego uznające, że posłużenie się personaliami kardynała Stefana Wyszyńskiego w nazwie komitetu wyborczego było sprzeczne z „chrześcijańskim dziedzictwem narodu"94. W celach argumentacyjnych do pojęcia tego nawiązał także sędzia Bohdan Zdziennicki w zdaniu odrębnym do wyroku Trybunału Konstytucyjnego dotyczącego tzw. lustracji ${ }^{95}$ oraz sędzia Jarosław Wyrembak w zdaniu odrębnym do wyroku Trybunału Konstytucyjnego w sprawie aborcji eugenicznej ${ }^{96}$. Nawet parlamentarzyści otwarcie deklarujący przywiązanie do moralności katolickiej i inspirowanie się nią nie są gotowi z przyczyn oportunistycznych wprowadzać reglamentacyjne rozwiązania prawne $\mathrm{w}$ zakresie aborcji, in vitro czy antykoncepcji.

Racji nie ma również L. Orgad. Nieuprawnione jest postrzeganie nawiązań do chrześcijaństwa w kategoriach „muzealnych”. Nawiązania te są świadectwem nie tylko historii, tego co minione, ale zarazem posiadają szeroko rozumiany wymiar cywilizacyjno-kulturowy. Chrześcijaństwo w wielu państwach wciąż pozostaje głównym źródłem aksjologii społecznej, nawet jeśli procesy laicyzacyjne sprawiły, że moralność chrześcijańska nie jest tak powszechnie aprobowana, jak jeszcze dekady temu. Ilekroć społeczeństwo danego państwa pozostaje kulturowo chrześcijańskie, to konstytucyjnych odwołań do chrześcijaństwa nie należy zawężać do sfery symboliki, choćby chodziło o treści wyrażone w preambułach, a nie postanowienia części artykułowej ustaw zasadniczych.

Odwołanie do chrześcijaństwa $\mathrm{w}$ preambule konstytucji, nawet jeśli samo w sobie nie posiada normatywnego charakteru, może, a w niektórych

93 Zob. https://sip.lex.pl/\#/ [dostęp: 01.09.2021].

94 Postanowienie Sądu Najwyższego z dnia 16 sierpnia 2005 r., III SW 12/05, LEX nr 328079.

95 Zdanie odrębne sędziego B. Zdziennickiego do wyroku Trybunału Konstytucyjnego z dnia 11 maja 2007 r., K 2/07, OTK-A 2007, Nr 5, poz. 48.

96 Zdanie odrębne sędziego J. Wyrembaka do wyroku Trybunału Konstytucyjnego z dnia 22 października 2020 r., K 1/20, OTK-A 2021, Nr 1. 
przypadkach nawet powinno, być uwzględnione przy interpretacji przepisów ustawy zasadniczej i ustaw zwykłych w ramach wykładni systemowej i funkcjonalnej, np. przy wykładni art. 25 ust. 2 Konstytucji RP ${ }^{97}$. Podobnie L. Garlicki podnosi, że ,punktem wyjścia i centralnym punktem odniesienia dla rozważań o konstytucyjnym pojęciu godności staje się ujmowanie tego pojęcia w chrześcijańskiej nauce społecznej"98. O tym, że konstytucyjne nawiązania do chrześcijaństwa mogą wpływać na procesy wykładni i stosowania prawa, świadczy orzecznictwo irlandzkiego Sądu Najwyższego ${ }^{99}$.

Większej operacjonalizacyjności konstytucyjnych odniesień do chrześcijaństwa nie sprzyja postawa przedstawicieli doktryny prawniczej, którzy zwykle nie poświęcają im większej uwagi przy egzegezie tekstu ustaw zasadniczych. Pojęcie chrześcijańskiego dziedzictwa Narodu z preambuły rodzimej ustawy zasadniczej nie stało się przedmiotem szerszego zainteresowania jurysprudencji, której reprezentanci o pojęciu tym jedynie wzmiankują ${ }^{100}$. Skąpy dorobek piśmienniczy nie może oddziaływać na praktykę prawniczą.

Z uwagi na kulturowy, a nie wyłącznie duchowo-sakralny wymiar religii, nie należy w konstytucyjnych odniesieniach do chrześcijaństwa każdorazowo i a priori upatrywać legitymizacji społecznej stratyfikacji, gdzie niechrześcijanie mieliby rzekomo być obywatelami drugiej kategorii. Gołosłowne i arbitralne jest twierdzenie o tym, że wzmianka o ,chrześcijańskim dziedzictwie” w konstytucji norweskiej przeczy równej godności obywateli o różnych światopoglądach ${ }^{101}$. Wyróżnienie religii, wyznania bądź kościoła ściśle powiązanego z dziejami danego państwa i Narodu oraz gromadzącego największą liczbę wyznawców nie jest per se źródłem alienacji osób wyznających mniejszościowe religie czy tych, którym bliski jest światopogląd bezwyznaniowy. Niektóre jednak sformułowania rzeczywiście mogą obiektywnie uchodzić za rodzące uzasadnione poczucie wykluczenia. Określenie w konstytucji całego Narodu jako chrześcijański

97 Por. Brzozowski 2011, 10.

98 Garlicki 2016.

99 Zob. np. Quinn's Supermarket v. Attorney General [1972] IR 1; McGee v. A.G. \& Anor [1973] IESC 2, [1974] IR 284; Norris v. A.G. [1983] IESC 3, [1984] IR 36; Corway v. Independent Newspapers (Ireland) Limited [1999] IESC 5, [1999] 4 IR 485.

100 Sobczak 2018, 188-189; Polak 2018, 425-439.

101 Trigg 2013, 64. 
(Samoa, Zambia) nolens volens komunikuje, że ustrojodawca odmawia niechrześcijanom statusu pełnoprawnych członków Narodu.

Konstytucyjne odniesienia do chrześcijaństwa nie pozostają w żadnym koniecznym związku z naruszeniem zasady równości wszystkich wobec prawa czy z ograniczeniem wolności sumienia $\mathrm{i}$ religii niechrześcijan ${ }^{102}$. Jedynie nieliczne przepisy wśród przeanalizowanych i przywołanych w niniejszym artykule można ewentualnie rozpatrywać jako zaprzeczenie postawionej tezie, np. wskazany art. 35 konstytucji Panamy. Możliwość wyznawania i praktykowania niechrześcijańskich religii i form kultu warunkuje on bowiem m.in. poszanowaniem „chrześcijańskiej moralności”. Nierzadko zresztą wrażenie o faworyzowaniu konkretnego wyznania czy kościoła jest mylne. Wymienienie z nazwy w rodzimej konstytucji Kościoła Katolickiego (art. 25 ust. 4) można thumaczyć tym, że Stolicy Apostolskiej i Państwu Watykańskiemu przysługuje podmiotowość prawnomiędzynarodowa i związana z tym zdolność kontraktowa ${ }^{103}$.

Wyróżnienie chrześcijaństwa w konstytucji z powodu jego doniosłości historycznej i kulturowej nie musi przeczyć zasadzie bezstronności czy neutralności religijnej władz publicznych. Zasada ta, jeśli jest właściwie rozumiana, oznacza przede wszystkim nieangażowanie się państwa w sprawy czysto religijne (teologiczne) ${ }^{104}$. Błędem jest wywodzenie z niej nakazu indyferentnej postawy władz publicznych względem moralności chrześcijańskiej. Państwo nie może być i nigdy nie jest aksjologicznie neutralne. Jeśli normy czy wartości chrześcijańskie uległy inkulturacji w danym społeczeństwie, to ustrojodawca eksponując je in genere w konstytucji, jedynie daje wyraz istniejącej społecznej aksjologii, na podobieństwo odwoływania się do np. humanizmu, liberalizmu czy socjalizmu. Moralność ukształtowana pod wpływem religii nie jest gorszą moralnością względem moralności determinowanej niereligijnymi doktrynami czy ideologiami.

Przywołanie w konstytucji chrześcijaństwa z reguły nie pociąga za sobą angażowania się czy mieszania się ustrojodawcy w kwestie religijnej natury sensu stricto, do czego nie posiada on merytorycznych kompetencji i co skutkowałoby podaniem w wątpliwość jego neutralności religijnej.

\footnotetext{
102 Kroczek 2017, 19-20.

103 Zob. Mezglewski 2005, 295-303.

104 Por. Łączkowski 2006, 209-219.
} 
Wyjątki są nieliczne, jak wspomniane zdefiniowanie „wartości chrześcijańskich" w ustawie zasadniczej Nikaragui czy zajmowanie się kwestią tłumaczenia Pisma Świętego w greckiej konstytucji ${ }^{105}$.

Nawiązania do chrześcijaństwa we współczesnych konstytucjach nie mają też nic wspólnego z „chrześcijańskim konstytucjonalizmem” rozumianym w kategoriach teokracji ${ }^{106}$. Często mylnie przypisuje się im te treści normatywne, których one nie wyrażają. Nieuprawnione i dające wyraz uprzedzeniom jest twierdzenie, że kultura „zakorzeniona w chrześcijańskiej tradycji nie może być demokratyczna" ${ }^{107}$.

\section{PODSUMOWANIE}

Od Konstytuanty decydującej o wprowadzeniu odniesień do chrześcijaństwa w konstytucji, zwłaszcza w preambule, należy wymagać responsywności wobec społecznych oczekiwań, pamiętając, że to Naród jest suwerenem. Odniesienia takie, podobnie jak cała konstytucja, powinny cieszyć się społeczną legitymizacją. Sondażowy stosunek Polaków do wskazanego powyżej pytania referendalnego Prezydenta RP pokazuje, że nawet społeczeństwo wyróżniające się religijnym zaangażowaniem na tle społeczeństw innych państw demoliberalnych, nie jest zainteresowane „nasycaniem” konstytucji treściami konfesyjnymi, zwłaszcza wówczas, gdy proponowane brzmienie odwołania do chrześcijaństwa w pewnym zakresie powielałoby odwołanie już zawarte we wstępie do ustawy zasadniczej ${ }^{108}$. Z drugiej strony nie ma powodów (lub są one nieprzekonujące), aby ustrojodawca nie mógł wyraźnie wskazać w konstytucji na chrześcijaństwo jako element historycznej, kulturowej i aksjologicznej tożsamości konkretnego Narodu.

${ }^{105}$ Obiekcje z tego samego powodu może budzić też określenie w preambule polskiej konstytucji przymiotów Boga, jako „źródła prawdy, sprawiedliwości, dobra i piękna”. Por. Mager 2021, 42-49; Domingo 2014, 147-167.

106 Zob. McKinley Brennan 2015, 478-540.

107 Paradowski 2009, 66.

108 Zainteresowanie referendum konsultacyjnym ws. Konstytucji, „Komunikat z badań CBOS" 2018, nr 95. Por. Fea, 2013. 


\section{BIBLIOGRAFIA}

Årsheim, Helge, Pamela Slotte. 2017. „The Juridification of Religion?”. Brill Research Perspectives in Law and Religion 1/2: 1-89.

Bała, Paweł. 2011. „Invocatio Dei w Konstytucji RP z 2 kwietnia 1997 r. w perspektywie porównawczej i historycznej”. Studia Erasmiana Wratislaviensia 5: 305-333.

Barbulescu, Iordan Gheorghe, Gabriel Andreescu. 2009. „References to God and the Christian Tradition in the Treaty Establishing a Constitution for Europe: An Examination of the Background". Journal for the Study of Religions and Ideologies 8 (24): 207-230.

Borden, Morton. 1979. „The Christian Amendment”. Civil War History 2 (25): $156-167$.

Borecki, Paweł. 2017. „Znamiona państwa wyznaniowego - uwagi na kanwie dorobku współczesnego konstytucjonalizmu". Studia z Prawa Wyznaniowego 20: 223-248.

Brzozowski, Wojciech. 2011. Bezstronność światopogladowa władz publicznych w Konstytucji RP. Warszawa: Wolters Kluwer.

Cvijic, Srdjan, Lorenzo Zucca. 2004. „Does the European Constitution need Christian Values?". Oxford Journal of Legal Studies 4 (24): 739-748.

Czuryk, Małgorzata. 2015. „Edukacja religijna w szkołach publicznych w Finlandii". Kościót i Prawo 1/4: 73-87.

Daniel, Krystyna. 1997. „Kontrowersje wokół wprowadzenia wartości chrześcijańskich do prawa”. W: Dynamika wartości w prawie, red. Krzysztof Pałecki, 157-207. Kraków: Księgarnia Akademicka.

Dineen, Kieran. 2017. Constitution to be stripped of any mention of Christianity under soon to be proposed bill, https://www.thesun.ie/news/961603/constitution-to-be-stripped-of-any-mention-of-christianity-under-soon-to-be-proposed-bill/ [dostęp: 01.09.2021].

Domingo, Rafael. 2014. „The Metalegal God”. Ecclesiastical Law Journal 16 (2): $147-167$.

Duda, Renata. 2006. „Aksjologiczne podstawy Unii Europejskiej: debata na temat chrześcijańskiego dziedzictwa Europy”. W: Unia Europejska i Polska wobec dylematów integracyjnych na poczatku XXI wieku, red. Mieczysław Stolarczyk, 71-80. Toruń: Wydawnictwo Adam Marszałek.

Fea, John. 2013. No surprise that 32\% of Americans want a Christian constitutional amendment, https://www.firstthings.com/blogs/firstthoughts/2013/04/no-surprisethat-of-americans-want-a-christian-constitutional-amendment [dostęp:01.09.2021]. 
Ferrari, Silvio. 2015. „The Christian roots of the secular state”. In: Mapping the legal boundaries. Religion and Multiculturalism from Israel to Canada, ed. René Provost, 25-40. New York: Oxford University Press.

Flere, Sergej, Miran Lavrič, Dragoljub Djordjević. 2017. „Religious References in the Constitutions of European Post-Communist Countries and Ethno-symbolism". Journal of Church and State 3 (59): 466-488.

Frosini, Justin. 2012. Constitutional preambles at a Crossroads Between Politics and Law. Rimini: Maggioli.

Garlicki, Leszek. 2016. „Komentarz do art. 30”. W: Konstytucja Rzeczypospolitej Polskiej. Komentarz, vol. 2, red. Leszek Garlicki, Marek Zubik, Warszawa: Wydawnictwo Sejmowe.

Gołda-Sobczak, Maria. 2008. „Systemy relacji między państwem a kościołami i związkami wyznaniowymi”. Środkowoeuropejskie Studia Polityczne 1: 61-110.

Henry, Eron. 2018. Constitutionally Religious: What the Constitutions of 180 Countries Say About Religion and Relief. Alexandria: b.d.

Iban, Iván. 2013. „God in Constitutions and Godless Constitutions”. In: Law, Religion, Constitution: Freedom of Religion, Equal Treatment, and the Law, eds. W. Cole Durham, Silvio Ferrari, Cristina Cianitto, Donlu Thayer, 37-55. Farnham: Ashgate.

Kavanagh, Aileen. 2012. „The Irish Constitution at 75 Years: Natural Law, Christian Values and the Ideal of Justice". Irish Jurist 48: 71-101.

Kozłowski, Krzysztof, Paweł Gomułka, Michał Latuszewski. 2006. „Chrześcijańskie dziedzictwo Europy jako problem konstytucyjny”. W: Człowiek wobec systemów wartości, red. Tomasz Kozłowski, Karol Kuźmicz, 126-137. Białystok: Wydawnictwo Temida 2.

Kroczek, Piotr. 2017. Prawo wewnętrzne związków wyznaniowych w perspektywie organów władzy publicznej: klauzule generalne. Kraków: Wydawnictwo Naukowe.

Krukowski, Józef. 1996. „«Invocatio Dei» w konstytucjach współczesnych państw demokratycznych. Refleksja w związku z debatą nad projektem Konstytucji RP”. Ethos: Kwartalnik Instytutu Jana Pawła II KUL 3/4: 202-214.

Kurian, George, Mark Lamport. 2016. Encyclopedia of Christianity in the United States, vol. 5. Lanham: Rowman \& Littlefield.

Łączkowski, Wojciech. 2006. „«Bezstronność» władz publicznych”. Ruch Prawniczy, Ekonomiczny i Socjologiczny 2: 209-219.

Łętowska, Ewa. 2018. Odwołanie do „chrześcijańskiego dziedzictwa” w złej wierze. Prof. Lętowska o pytaniach konstytucyjnych Dudy, https://oko.press/ 
odwolanie-do-chrzescijanskiego-dziedzictwa-w-zlej-wierze-prof-letowska-o-pytaniach-konstytucyjnych-dudy/ [dostęp: 01.09.2021].

Madeley, John. 2017. „The Curious Case of Religion in the Norwegian Constitution". In: Constitution Writing, Religion and Democracy, eds. Asli Bâli, Hanna Lerner, 29-48. Cambridge: Cambridge University Press.

Mager, Robert. 2021. „God in National Constitutions: A Liberating Reference?”. International Academy of Practical Theology. Conference Series 2: 42-49.

Maroń, Grzegorz. 2019. „Odwołania do Boga w konstytucjach państw współczesnych. Studium komparatystyczne". Studia z Prawa Wyznaniowego 22: 5-40.

McKinley Brennan, Patrick. 2015. „An Essay on Christian Constitutionalism: Building in the Divine Style, for the Common Good(s)". Rutgers Journal of Law and Religion 16/3: 478-540.

Menéndez, Agustín José. 2005. „A Christian or a Laïc Europe. Christian Values and European Identity". Ratio Juris 2 (18): 179-205.

Naumann, Kolja. 2008. Eine religiöse Referenz in einem Europäischen Verfassungsvertrag. Tübingen: Mohr Siebeck.

Neo, Jaclyn. 2017. „Express Recognition of Deity in Constitutions”. In: Max Planck Encyclopedia of Comparative Constitutional Law, eds. Rainer Grote, Frauke Lachenmann, Rüdiger Wolfrum. Oxford: Oxford University Press.

Orgad, Liav. 2017. The Cultural Defense of Nations. A Liberal Theory of Majority Rights. Oxford: Oxford University Press.

Orzeszyna, Krzysztof. 2007. Podstawy relacji między państwem a Kościołami w konstytucjach państw członkowskich i traktatach Unii Europejskiej. Lublin: Wydawnictwo KUL.

Paradowski, Ryszard. 2009. „God and Constitution. Polish constitutional confusion”. Zeszyty Naukowe Dolnośląskiej Wyższej Szkoły Przedsiębiorczości i Techniki w Polkowicach. Studia z Nauk Spolecznych 2: 61-68.

Polak, Piotr. 2018. „The normative value of the reference to God and Christianity in the preamble to the Constitution of the Republic of Poland of 2nd April, 1997". Przeglad Prawa Konstytucyjnego 6: 425-439.

Safjan, Marek. 2003. „Wolność religijna w konstytucjach państw europejskich”. W: Kultura i prawo, t. 3: Religia i wolność religijna w Unii Europejskiej, red. Józef Krukowski, Otto Theisen, 43-73. Lublin: Towarzystwo Naukowe Katolickiego Uniwersytetu Lubelskiego.

Sobczak, Jacek. 2018. „Pojęcie dziedzictwa narodowego w świetle regulacji konstytucyjnych". Przeglad Prawa Konstytucyjnego 5: 187-208.

Suchocka, Hanna. 2008. „Sens sporu o korzenie chrześcijańskie w Konstytucji europejskiej”. W: Ksiega jubileuszowa Prof. dr hab. Tadeusza Smyczyńskiego, red. Marek Andrzejewski, 733-743. Toruń: TNOiK „Dom Organizatora”. 
Szymanek, Jarosław (red.). 2011. Państwo wyznaniowe: doktryna, prawo i praktyka. Warszawa: Elipsa.

Temperman, Jeroen. 2010. State-Religion Relationships and Human Rights Law: Towards a Right to Religiously Neutral Governance. Leiden-Boston: Brill.

Trigg, Roger. 2013. Equality, Freedom, and Religion. Oxford: Oxford University Press.

Voermans, Wim, Maarten Stremler, Paul Cliteur. 2017. Constitutional preambles. A comparative analysis. Cheltenham - Northampton: Edward Elgar Publishing. Yakobson, Alexander. 2013. „God and Religion in Modern Democratic Constitutions". In: The nation state and religion: the resurgence of faith, eds. Anita Shapira, Yedidia Stern, Alexander Yakobson, 1-13. Brighton: Sussex Academic Press.

\section{ZAŁĄCZNIK}

Wykaz przywołanych konstytucji wraz z podaniem źródła tekstu w języku urzędowym (data dostępu we wszystkich przypadkach: 01.09.2021)

Konstytucja Księstwa Andory z dnia 14 marca 1993 r., http://www.consellgeneral.ad/ ca/el-consell-dandorra/constitucio-i-reglament/la-constitucio-del-principat-d-andorra; thum. Mariusz Bobiński. 2014. Warszawa: Wydawnictwo Sejmowe, https:// biblioteka.sejm.gov.pl/wp-content/uploads/2015/05/Andora_pol010814.pdf

Konstytucja Republiki Argentyńskiej z dnia 1 maja 1853 r., http://www.saij.gob.ar/ nacional-constitucion-nacional-constitucion-nacion-argentina-lns0002665-199 4-08-22/123456789-0abc-defg-g56-62000scanyel

Konstytucja Ludowej Republiki Bangladeszu z dnia 4 listopada 1972 r., http:// bdlaws.minlaw.gov.bd/act-367.html

Konstytucja Wspólnoty Bahamów z dnia 20 czerwca 1973 r., laws.bahamas.gov. bs/cms/images/LEGISLATION/PRINCIPAL/1973/1973-1080/TheConstitution_1.pdf

Konstytucja Republiki Bułgarii z dnia 12 lipca 1991 r., https://www.parliament.bg/ bg/const; tłum. Hanna Karpińska. 2012. Warszawa: Wydawnictwo Sejmowe, libr.sejm.gov.pl/tek01/txt/konst/bulgaria2013.pdf

Konstytucja Królestwa Danii z dnia 5 czerwca 1953 r., https://www.ft.dk/ /media/ sites/ft/pdf/publikationer/grundloven/grundloven_samlet_2018_dk_web.ashx; thum. Marian Grzybowski. 2011. W: Konstytucje państw Unii Europejskiej, red. Wiesław Staśkiewicz, 213-225. Warszawa: Wydawnictwo Sejmowe, http:// biblioteka.sejm.gov.pl/wp-content/uploads/2015/07/Dania_pol_010811.pdf 
Konstytucja Republiki Dominikany z dnia 13 czerwca 2015 r., https://mepyd.gob.do/ wp-content/uploads/drive/Transparencia/Base\%20legal\%20de\%20la\%20institucion/Constitucion/Constitucio\%CC\%81n\%20Dominicana\%202015.pdf

Konstytucja Arabskiej Republiki Egiptu z dnia 18 stycznia 2014 r., www.sis.gov.eg/ Newvr/consttt\%202014.pdf

Konstytucja Republiki Fidżi z dnia 6 września 2013 r., https://www.fiji.gov.fj/ About-Fiji/Fijian-Constitution

Konstytucja Republiki Finlandii z dnia 11 czerwca 1999 r., http://www.finlex.fi/ fi/laki/ajantasa/1999/19990731; thum. Joachim Osiński. 2011. W: Konstytucje państw Unii Europejskiej, red. Wiesław Staśkiewicz, 249-270. Warszawa: Wydawnictwo Sejmowe, https://biblioteka.sejm.gov.pl/wp-content/uploads/2015/05/Finlandia_pol010811.pdf

Konstytucja Republiki Ghany z dnia 28 kwietnia 1992 r., https://www.judicial.gov. gh/index.php/preamble

Konstytucja Republiki Greckiej z dnia 9 czerwca 1975 r., https://www.hellenicparliament.gr/UserFiles/8c3e9046-78fb-48f4-bd82-bbba28ca1 ef5/SYNTAGMA.pdf; tłum. Grażyna i Włodzimierz Uliccy, Bartłomiej Zdaniuk, Natalia Ciesielczyk. 2011. W: Konstytucje państw Unii Europejskiej, red. Wiesław Staśkiewicz, 297-340. Warszawa: Wydawnictwo Sejmowe, http://biblioteka. sejm.gov.pl/wp-content/uploads/2015/10/Grecja_pol_010711.pdf

Konstytucja Gruzji z dnia 24 sierpnia 1995 r., https://matsne.gov.ge/ka/document/ view/30346?publication=35; thum. Grzegorz Kuca, Marian Grzybowski, Katarzyna Kaczmarczyk-Kłak. 2015. Warszawa: Wydawnictwo Sejmowe, http:// biblioteka.sejm.gov.pl/wp-content/uploads/2016/01/Gruzja_pol_010715.pdf

Konstytucja Republiki Gwatemali z dnia 31 maja 1985 r., https://guatemala.justia. com/nacionales/constitucion-de-la-republica-de-guatemala/

Konstytucja Republiki Haiti z dnia 10 marca 1987 r., http:/www.omrh.gouv.ht/ Media/Publications/1-Constitution/Constitution1987Amend\%C3\%A9eJuin2 012.pdf

Konstytucja Królestwa Hiszpanii z dnia 27 grudnia 1978 r., https://www.lamoncloa.gob.es/espana/leyfundamental/Paginas/index.aspx; thum. Tadeusz Mołdawa. 2011. W: Konstytucje państw Unii Europejskiej, red. Wiesław Staśkiewicz, 241-374. Warszawa: Wydawnictwo Sejmowe, https://biblioteka.sejm. gov.pl/wp-content/uploads/2015/10/Hiszpania_pol_300612.pdf

Konstytucja Republiki Iraku z dnia 15 października 2005 r., http://ar.parliament.iq/ \%D8\%A7\%D9\%84\%D8\%AF\%D8\%B3\%D8\%AA\%D9\%88\%D8\%B1-\%D8 \%A7\%D9\%84\%D8\%B9\%D8\%B1\%D8\%A7\%D9\%82\%D9\%8A/

Konstytucja Islamskiej Republiki Iranu z dnia 24 października 1979 r., https://mfa. gov.ir/portal/viewpage/3991 
Konstytucja Republiki Irlandii z dnia 1 lipca 1937 r., https://www.gov.ie/en/publication/d5bd8c-constitution-of-ireland/; thum. Sabina Grabowska. 2011. W: Konstytucje państw Unii Europejskiej, red. Wiesław Staśkiewicz, 393-417. Warszawa: Wydawnictwo Sejmowe, http://biblioteka.sejm.gov.pl/wp-content/uploads/2015/11/Irlandia_pol_010711.pdf

Konstytucja Republiki Islandii z dnia 17 czerwca 1944 r., https://www.althingi.is/ lagas/nuna/1944033.html; tłum. Joachim Osiński. 2009. Warszawa: Wydawnictwo Sejmowe. https://biblioteka.sejm.gov.pl/wp-content/uploads/2015/11/ Islandia_pol_010110.pdf

Akt konstytucyjny Kanady z dnia 17 kwietnia 1982 r., https://laws-lois.justice.gc.ca/ eng/Const/index.html; thum. Joachim Osiński, Izabela Zawiślińska. 1998. Warszawa: Wydawnictwo Sejmowe, http://biblioteka.sejm.gov.pl/wp-content/uploads/2016/01/Kanada_pol_010496.pdf

Konstytucja Republiki Kostaryki z dnia 8 listopada 1949 r., https://www.pgrweb.go.cr/ scij/Busqueda/Normativa/Normas/nrm_texto_completo.aspx?nValor1=1\&n Valor2 $=871$

Konstytucja Republiki Libanu z dnia 23 maja 1926 r., https://www.presidency.gov. $\mathrm{lb} /$ Arabic/LebaneseSystem/Documents/LebaneseConsitution.pdf

Konstytucja Księstwa Lichtensteinu z dnia 5 października 1921 r., https://www. gesetze.li/konso/1921015000; thum. Radosław Grabowski. 2013. Warszawa: Wydawnictwo Sejmowe, http://biblioteka.sejm.gov.pl/wp-content/uploads/2016/01/Liechtenstein_pol_010712.pdf

Konstytucja Republiki Łotewskiej z dnia 15 lutego 1922 r., https://likumi.lv/doc. php?id=57980; thum. Lidia Gołubiec, Iwona Jaroszkiewicz. 2011. W: Konstytucje państw Unii Europejskiej, red. Wiesław Staśkiewicz, 459-470. Warszawa: Wydawnictwo Sejmowe, http://biblioteka.sejm.gov.pl/wp-content/uploads/ 2016/11/Lotwa_pol_010711.pdf

Konstytucja Republiki Północnej Macedonii z dnia 17 listopada 1991 r., https:// www.sobranie.mk/content/Odluki\%20USTAV/UstavSRSM.pdf; thum. Teresa Wójcik. 1999. Warszawa: Wydawnictwo Sejmowe, https://libr.sejm.gov.pl/ tek01/txt/konst/macedonia.html

Konstytucja Republiki Malty z dnia 21 września 1964 r., http://www.justiceservices.gov.mt/DownloadDocument.aspx?app=lom\&itemid=8566\&l=2; thum. Jan Winczorek. 2011. W: Konstytucje państw Unii Europejskiej, red. Wiesław Staśkiewicz, 471-518. Warszawa: Wydawnictwo Sejmowe, http://biblioteka .sejm.gov.pl/wp-content/uploads/2016/02/Malta_pol_010711.pdf

Konstytucja Księstwa Monako z dnia 17 grudnia 1962 r., https://www.gouv.mc/ Gouvernement-et-Institutions/Les-Institutions/La-Constitution-de-la-Principaute; thum. Agnieszka Wojtyczek-Bonnand, Krzysztof Wojtyczek. 2012. Warszawa: Wydawnictwo Sejmowe, http://libr.sejm.gov.pl/tek01/txt/konst/monako2013.pdf 
Konstytucja Republiki Związku Myanmar z dnia 29 maja 2008 r., www.burmalibrary.org/docs5/Myanmar_Constitution-2008-en.pdf

Konstytucja Republiki Nikaragui z dnia 19 listopada 1986 r., https://www.asamblea.gob.ni/assets/constitucion.pdf

Konstytucja Królestwa Norwegii z dnia 17 maja 1814 r., https://lovdata.no/dokument/NL/lov/1814-05-17; tłum. Joachim Osiński. 1996. Warszawa: Wydawnictwo Sejmowe, http://biblioteka.sejm.gov.pl/wp-content/uploads/2016/02/ Norwegia_pol_010196.pdf

Konstytucja Islamskiej Republiki Pakistanu z dnia 14 sierpnia 1973 r., http://www. na.gov.pk/uploads/documents/1391139448_469.pdf

Konstytucja Republiki Panamy z dnia 11 października 1972 r., https://ministeriopublico.gob.pa/wp-content/uploads/2016/09/constitucion-politica-con-indice-analitico.pdf

Konstytucja Niezależnego Państwa Papui Nowej Gwinei z dnia 16 sierpnia 1975 r., http://www.parliament.gov.pg/constitution-of-the-independent-state-of-papua-new-guinea

Konstytucja Republiki Paragwaju z dnia 20 czerwca 1992 r., www.mre.gov.py/v2/ Adjuntos/Normativas/CONSTITUCIONNACIONAL.pdf

Konstytucja Republiki Peru z dnia 29 grudnia 1993 r., http://www.leyes.congreso. gob.pe/Documentos/constituciones_ordenado/CONSTIT_1993/Texto_actualizado_CONS_1993.pdf

Konstytucja Rzeczypospolitej Polskiej z dnia 2 kwietnia 1997 r., Dz. U. z 1997 r. $\mathrm{Nr} 78$, poz. 483 z późn. zm.

Konstytucja Republiki Salwadoru z dnia 15 grudnia 1983 r., https://www.asamblea.gob.sv/sites/default/files/documents/decretos/F0DD4DE1-8CCA-461B-B1CB-0D04D37B4FD1.pdf

Konstytucja Niezależnego Państwa Samoa z dnia 28 października 1960 r., https:// www.palemene.ws/wp-content/uploads/Constitution-Sam.pdf

Konstytucja Republiki San Marino (Statuty z dnia 8 października 1600 r.), https:// www.consigliograndeegenerale.sm/on-line/home/archivio-leggi-decreti-e-regolamenti/scheda17009068.html

Konstytucja Republiki Słowackiej z dnia 1 września 1992 r., https://www.ustavnysud.sk/ ustava-slovenskej-republiky; thum. Krzysztof Skotnicki. 2011. W: Konstytucje państw Unii Europejskiej, red. Wiesław Staśkiewicz, 693-724. Warszawa: Wydawnictwo Sejmowe, http://biblioteka.sejm.gov.pl/wp-content/uploads/2016/11/Slowacja_ pol_010711.pdf

Konstytucja Królestwa Szwecji (Akt o sukcesji z dnia 26 września 1810 r.), https:// www.riksdagen.se/sv/dokument-lagar/dokument/svensk-forfattningssamling/ successionsordning-18100926_sfs-1810-0926; thum. Krzysztof Dembiński, Marian Grzybowski. 2011. W: Konstytucje państw Unii Europejskiej, 
red. Wiesław Staśkiewicz, 749-816. Warszawa: Wydawnictwo Sejmowe, http:// biblioteka.sejm.gov.p1/wp-content/uploads/2016/04/Szwecja_pol_010711.pdf

Konstytucja Demokratycznej Republiki Timoru Wschodniego z dnia 22 marca 2002 r., http://timor-leste.gov.tl/?cat=37\&lang=pt

Konstytucja Tuvalu z dnia 1 października 1986 r., http://tuvalu-legislation.tv/cms/ images/LEGISLATION/PRINCIPAL/1986/1986-0001/ConstitutionofTuvalu_1.pdf

Konstytucja Republiki Urugwaju z dnia 27 listopada 1967 r., https://parlamento.gub. uy/documentosyleyes/constitucion

Konstytucja Republiki Vanuatu z dnia 23 października 1979 r., https://www.gov. vu/index.php/about/constitution-of-vanuatu

Konstytucja Watykanu (Ustawa zasadnicza Państwa Miasto Watykan z dnia 26 listopada 2000 r.), http://www.vatican.va/news_services/press/documentazione/ documents/sp_ss_scv/informazione_generale/legge-fondamentale_it.html; thum. Franciszek Longchamps de Bérier, Marek Zubik. 2008. Warszawa: Wydawnictwo Sejmowe, https://libr.sejm.gov.pl/tek01/txt/konst/watykan.html

Konstytucja Węgier z dnia 18 kwietnia 2011 r., https:/www.parlament.hu/ irom39/02627/02627-0187.pdf; thum. Jerzy Snopek. 2015. Warszawa: Wydawnictwo Sejmowe, http://libr.sejm.gov.pl/tek01/txt/konst/wegry2013.pdf

Ustawy ustrojowe Zjednoczonego Królestwa Wielkiej Brytanii i Irlandii Północnej, www.legislation.gov.uk; thum. Sebastian Kubas. 2011. W: Konstytucje państw Unii Europejskiej, red. Wiesław Staśkiewicz, 871-976. Warszawa: Wydawnictwo Sejmowe.

Konstytucja Republiki Włoskiej z dnia 27 grudnia 1947 r., http://www.senato.it/1024; thum. Zbigniew Witkowski. 2011. W: Konstytucje państw Unii Europejskiej, red. Wiesław Staśkiewicz, 845-870. Warszawa: Wydawnictwo Sejmowe, http:// biblioteka.sejm.gov.pl/wp-content/uploads/2016/11/Wlochy_pol_010711.pdf

Konstytucja Republiki Zambii z dnia 30 sierpnia 1991 r., http://www.parliament.gov. $\mathrm{zm} /$ sites/default/files/documents/amendment_act/Constitution\%20of\%20Zambia\%20\%20\%28Amendment $\% 29 \% 2$ C\%202016-Act $\% 20$ No.\%202_0.pdf 